\title{
Effect of Climatic Variables on Abundance and Dispersal of Lecanosticta acicola Spores and Their Impact on Defoliation on Eastern White Pine
}

\author{
S. A. Wyka, C. D. McIntire, C. Smith, I. A. Munck, B. N. Rock, H. Asbjornsen, and K. D. Broders ${ }^{\dagger}$
}

First, third, and seventh authors: Department of Biological Sciences, and second, fifth, and sixth authors: Department of Natural Resources and the Environment, University of New Hampshire, Durham 03824; first and seventh authors: Department of Bioagricultural Sciences and Pest Management, Colorado State University, Fort Collins 80523; and fourth author: NA State \& Private Forestry, U.S. Department of Agriculture Forest Service, Durham, NH 03824. Accepted for publication 16 October 2017.

\begin{abstract}
The disease complex white pine needle damage (WPND), first reported in 2006, has now escalated to an epidemic state across the northeastern United States. Although this complex is composed of several fungal species, Lecanosticta acicola is considered to be the primary causal agent. Knowledge regarding the epidemiology, specific climatic factors that affect the spread of L. acicola on eastern white pine (Pinus strobus) in natural forest settings, and potential risks repeated defoliation may have on tree health is limited. Therefore, this study examined how climatic variables affect the abundance and distance of spore dispersal of L. acicola and compared litterfall caused by defoliation versus natural needle abscission. Conidia were
\end{abstract}

ABSTRACT

Previous research on white pine needle damage (WPND), which affects eastern white pine (Pinus strobus L.) across the northeastern United States, has revealed that four fungal species-Lecanosticta acicola (Thüm.) Syd., Bifusella linearis (Peck) Höhn, Lophophacidium dooksii Corlett \& Shoemaker, and Septorioides strobi Wyka \& Broders-are commonly associated with WPND-induced defoliation events (Broders et al. 2015; Munck et al. 2012; Wyka and Broders 2016; Wyka et al. 2017). Of these species, Lecanosticta acicola (previously known as Mycosphaerella dearnessi) (Quaedvlieg et al. 2012) is considered the primary fungal pathogen responsible for disease symptom development and defoliation on eastern white pine (Broders et al. 2015), and, thus, is the focal species of this study. Previous studies mainly focused on monitoring and determining which fungal pathogens were most frequently associated with WPND symptoms. However, Broders et al. (2015) showed that asymptomatic needles from healthy eastern white pine stands did not produce fungal fruiting bodies and that asymptomatic trees did not shed their needles. They further determined that WPND is spreading from symptomatic to initially healthy trees and suggested that unusually wet springs were the cause of the spread. To develop management strategies, it is necessary to understand the epidemiology and spread of this native forest pathogen. Therefore, this study will determine the effects of environmental factors on dispersal patterns of $L$. acicola and the potential effects it has on the foliar biomass and growth response of mature eastern white pine.

${ }^{\dagger}$ Corresponding author: K. D. Broders; E-mail: kirk.broders@ colostate.edu

This work was funded by the U.S. Forest Service Evaluation Monitoring grant number NE-EM-B-13-03.

*The $\boldsymbol{e}$-Xtra logo stands for "electronic extra" and indicates that two supplementary figures are published online.

(c) 2018 The American Phytopathological Society observed on spore traps from May through August, with a peak in abundance occurring in June, corresponding to the defoliation of second- and third-year foliage measured in litter traps. During peak spore production, relative humidity and the occurrence of rainfall was found to have the greatest influence on spore abundance. Our results will aid managers in determining how far from infected trees natural regeneration will likely be affected and predicting future disease severity based on climatic conditions.

Additional keywords: brown spot needle blight, foliar pathogen, spore trapping

L. acicola, a filamentous ascomycete and foliar pathogen causing brown spot needle blight, is known to infect at least 28 species of pine across a large geographic range, including North America, South America, Central America, Europe, and Asia (Boyce 1959; EPPO/CABI 2013; Gibson 1980; Hintsteiner et al. 2012; Jankovský et al. 2009, Jurc and Jurc 2010; OEPP/EPPO 2005; Phelps et al. 1978; Skilling and Nicholls 1974). However, brown spot needle blight is most broadly recognized for its outbreaks in the southeastern and northcentral regions of the United States, where it has caused significant economic losses to both longleaf pine (P. palustris Mill.) and Scots pine (P. sylvestris L.) plantations (Heimann et al. 1997; Huang et al. 1995; Phelps et al. 1978; Siggers 1944; Skilling and Nicholls 1974). These outbreaks resulted in the prioritization of previous research concerning the etiology and epidemiology of L. acicola on longleaf and Scots pine (Heimann et al. 1997; Kais 1971, 1975; Phelps et al. 1978; Skilling and Nicholls 1974).

In Scots pine and longleaf pine, L. acicola infects needles in the spring through the stomata, causing symptoms to develop on current-year needles in August, and causing needles of all ages to drop in the autumn of the same year (Heimann et al. 1997; Kais 1971, 1975; Phelps et al. 1978; Skilling and Nicholls 1974). However, on eastern white pine, L. acicola symptoms have only been observed on second- and third-year needles (1- and 2-year-old needles) after a full-year incubation period, with defoliation of the current-year needles occurring the following spring and not during the autumn immediately following infection (Boyce 1959; Munck et al. 2012; Stanosz et al. 1991). Symptomology is also quite distinct on eastern white pine because needles do not turn brown but, rather, turn fully chlorotic with green dots where acervuli form as opposed to the "brown spot" seen on Scots and longleaf pine. It should be noted that eastern white pine is a five-needle pine which is quite different taxonomically from Scots and longleaf pine, which are two- and three-needle pine. Additionally, infection is localized to the lower portion of the tree crown, with disease slowly progressing upward over several consecutive years of defoliation (Boyce 1959; 
Munck et al. 2012). This disease results in eastern white pine exhibiting thin crowns, with infected branches that contain only the new emergent needles of the current growing season. Similarly, La Porta and Capretti (2000) observed that L. acicola affected only the second- and third-year needles on mountain pine ( $P$. mugo Turra.), with symptoms arising in the spring and initially occurring on the bottom portion of the crown. Other variations in the onset of brown spot needle blight between tree species and in the degree of virulence between $L$. acicola isolates, even within a specific geographic area, have been indicated by numerous studies and reports (Holdenrieder and Sieber 1995; Huang et al. 1995; Jankovský et al. 2009; Jurc and Jurc 2010; La Porta and Capretti 2000; Phelps et al. 1978; Skilling and Nicholls 1974).

The increase in spring and summer rain in the northeastern region of the United States over the past decade may be contributing to the current WPND outbreaks (Wyka et al. 2017), because L. acicola spore release has been correlated to the occurrence of rainfall and low temperatures (Skilling and Nicholls 1974). In an L. acicola spore dispersal study, Skilling and Nicholls (1974) placed petroleumjelly-coated microscope slides within infected Scots pine Christmas tree plantations in Wisconsin and Minnesota. Their results demonstrated that mature acervuli of $L$. acicola release conidia (asexual spores) from May to September, with major infections occurring during June and July. In addition, ascospores (sexual spores) were not reported from their study. The lack of ascospores in the northern regions of the United States was recently confirmed by Janoušek et al. (2016), who determined that L. acicola isolates in this region are dominated by a population of a single haplotype (MAT1), indicating very infrequent sexual recombination.

In general, more conidia were released directly under the tree, with spores rarely observed more than $3.05 \mathrm{~m}$ away from an infected tree (Skilling and Nicholls 1974). Along with rainfall, other studies of L. acicola have indicated that both high moisture (leaf wetness) and relative humidity are necessary for conidial dissemination, production, and germination (EPPO/CABI 2013; Kais 1975). Although Skilling and Nicholls' (1974) research advanced basic understanding of the dispersal pattern of L. acicola, their research was conducted in a nonnatural setting with trees $<3.05 \mathrm{~m}$ tall. Consequently, these data do not provide adequate knowledge of dispersal patterns for foresters and land owners who manage natural forests with mature trees $>30 \mathrm{~m}$ tall. In addition, Skilling and Nicholls (1974) used windbreaks and Christmas tree plantations in their study, which have different microclimates compared with forest stands (Aussenac 2000). These differences, such as higher relative humidity in closed-canopy forest stands, could influence spore production.

Defoliation caused by WPND may also be affecting the foliar biomass and growth of infected trees. The amount of foliar biomass a tree maintains has been shown to be directly related to its net primary productivity throughout the growing season (Hinckley et al. 1999). Furthermore, the foliar mass in both deciduous and conifer tree species is proportional to the total aboveground biomass for individual trees (Reich 1998). In loblolly pine (P. taeda L.), for example, stemwood growth was found to have a positive linear relationship with leaf area index, estimated using litterfall trapping methods (Vose and Allen 1988). Therefore, the premature abscission of second- and third-year needles induced by WPND on eastern white pine in the summer months is hypothesized to have a direct impact on tree productivity due to a substantial reduction in net carbon assimilation during the height of the growing season. This is of importance because tree death due to WPND has only recently been observed, and it is unknown whether mortality rates will increase (Munck et al. 2012). Quantifying and comparing litterfall caused by summer defoliation to litterfall caused by natural needle abscission in the fall will provide insight into the potential growth risks related to multiple successive years of needle defoliation.

Litterfall trapping is often used to estimate the foliar component of annual aboveground tree productivity; thus, few studies capture litterfall dynamics on a subannual scale. A study of seasonal litterfall rates of eastern white pine stands in Ontario, Canada assessed accumulation of needle fall for nine collection dates in April through December and found a relatively constant rate of second- and thirdyear needle abscission occurring between May and the end of July, accounting for approximately 10 to $15 \%$ of the annual total, whereas the litterfall in October accounts for the overwhelming majority of the annual total (approximately 60\%) (Wang and Chen 2012). It is important to note in the context of this study that typical litterfall of eastern white pine occurring in the summer months is historically very low and most likely a product of wind and crown abrasion between neighboring trees. WPND-induced defoliation in recent years has consistently been observed in late June and early July (Munck et al. 2012). This study aims to quantify the precise timing and magnitude of these defoliation events using litterfall trapping.

Epidemiological studies of native forest pathogens in natural settings are relatively rare, possibly due to little appreciation for the impact that native pathogens have on natural forests (Hansen and Goheen 2000). However, concern regarding WPND is increasing from both public and private land owners because eastern white pine is not only an essential economic lumber resource but also a crucial ecological component of the forest of the northern United States and eastern Canada. Knowledge of dispersal patterns within managed stands and information regarding the potential risks of long-term tree health will allow foresters to offer comprehensive management recommendations. This study has the following objectives: (i) determine how climatic variables affect spore abundance and spore dispersal distance from individual infected trees and (ii) quantify litterfall caused by defoliation in June relative to litterfall caused by natural abscission in October. Combined, results from this study will help guide future research aimed at assessing impacts of WPND on the foliar biomass, growth responses, and mortality of infected trees.

\section{MATERIALS AND METHODS}

Spore dispersal sampling. This study was conducted at the Massabesic Experimental Forest (MEF), a research forest owned and managed by the Northern Research Station of the United States Department of Agriculture Forest Service in Lyman, ME (Supplementary Fig. S1). The land is relatively flat, with elevation ranging from 61 to $137 \mathrm{~m}$ and stony to sandy loam soils of glacial origin over granite bedrock (Stone 2006). Following a fire in 1947 that burned much of the landscape, the forest regenerated to northern hardwoods and eastern white pine (Stone 2006). Recent management of eastern white pine in fall 2007 left four clear cuts approximately $122 \mathrm{~m}$ in diameter each. In 2012, the MEF was designated as a representative forest affected by the current WPND outbreak (Munck et al. 2012). Sixteen trees were selected for annual monitoring of yellowing and defoliation severity caused by WPND and ranked on an ordinal scale, where $0=$ crown was asymptomatic, $1=$ defoliation occurred on the lower one-third of the crown, 2 = defoliation occurred on two-thirds of the crown, and $3=$ greater than two-thirds of the crown was defoliating (Munck et al. 2012). Three trees classified as highly infected with L. acicola bordered a large clear cut and, therefore, were chosen as source trees for this spore-dispersal study. Tree number 676 and number 678 received a disease severity rating of 3 and tree number 670 received a rating of 2 in 2014.

Ten spore traps were constructed to passively sample spores throughout the 2014 and 2015 growing seasons (Supplementary Fig. S2). Spore traps were $1.8 \mathrm{~m}$ tall and contained four branched supports angled at $45^{\circ}$ in the direction of each target tree, except for one support, placed in the center of the clear cut, which was laid flat. Each of the four supports contained a microscope slide with an area of $10 \mathrm{~cm}^{2}$ divided into four quadrants and covered by a thin coat of petroleum jelly (Bingzhang et al. 1992; Boateng and Lewis 2015; Podger 1978). Three spore traps were arranged in line with the source tree toward the center of the clear cut, while avoiding white pine regeneration. Spore traps were taller than all surrounding 
vegetation. In some cases, small white pine regeneration $(<1 \mathrm{~m}$ in height) could not be avoided; however, Pietravalle et al. (2001) demonstrated through modeling trajectories that rain-splash spores rarely dispersed $>0.3 \mathrm{~m}$ in height. The first spore trap was placed at $0 \mathrm{~m}$ from the branch tips of the lower crown and the subsequent two spore traps were placed at $3.05-\mathrm{m}$ intervals from the first spore trap. Previously, Skilling and Nicholls (1974) observed L. acicola spores dispersed up to $3.05 \mathrm{~m}$ from source trees. This interval was used because the authors wanted to determine maximum spore distance while taking into account the trajectory of spores dispersed from the crown, which was approximately $12 \mathrm{~m}$ above the spore traps. The spore trap in the center of the clear cut, approximately $60.6 \mathrm{~m}$ from the source trees, was placed to determine whether spores were capable of dispersing this distance and was not used in statistical analysis. All microscope slides were collected and replaced at 4-day intervals from 5 May to 29 August 2014. Spore sampling did not extend past August because the newly infected current-year needles of eastern white pine do not produce acervuli until the following spring (Boyce 1959; Munck et al. 2012; Stanosz et al. 1991). The sampling period in 2015 was shortened from 5 May to 1 August based on results obtained in 2014 because cumulative spore release plateaued during the month of August despite high relative humidity and consistent rainfall. In addition, data in 2014 showed that May to July were the most relevant months for $L$. acicola spore dispersal. Slides were examined under a compound microscope at $\times 100$ magnification to count the number of spores present in two randomly selected quadrants of the $10-\mathrm{cm}^{2}$ sampling area (Boateng and Lewis 2015). Microscope slides that collected fallen infected needles containing sporulating L. acicola acervuli were not included in the analyses because these slides exhibited an unrepresentative excess number of spores and were deemed outliers. Conidia were identified based on the morphological description of $L$. acicola described previously and were easily distinguished from other spores due to their slight crescent shape and olive color (Jankovský et al. 2009; OEPP/EPPO 2005).

Litterfall sampling. Litterfall was measured during the 2014, 2015, and 2016 growing seasons on three 30-by-30- $\mathrm{m}^{2}$ plots established within pine-dominated stands surrounding the clear cut. Litter traps were constructed from $0.18-\mathrm{m}^{2}$ rectangular baskets and lined with a fine mesh screen. Five litter traps were randomly located within each plot using a tessellated random sampling design. All litter was collected on a monthly basis starting on 1 May and ending 31 October of each year, corresponding with natural needle abscission (Wang and Chen 2012). Prior to the start of the annual study period, all litter traps were cleaned and repaired in late April. Upon collection, foliar material was stored in paper bags and oven dried at $70^{\circ} \mathrm{C}$ for 48 h. Dried litter was visually sorted for eastern white pine foliage and weighed to $0.01-\mathrm{g}$ precision using an electronic balance. In June, 2014 an inventory of litterfall plots was conducted in which diameter at breast height ( $1.3 \mathrm{~m}$ above ground level) for all stems $>10 \mathrm{~cm}$ was measured to determine the basal area (in square meters) contribution of eastern white pine within each experimental plot. Litterfall measurements were converted to a dry weight per area basis (in grams per square meters) and normalized for the relative basal area of eastern white pine (in square meters) to account for differences in stem density between plots. Significant differences between mean monthly litterfall were analyzed using a Student's $t$ test for each year of the study to determine whether summer months had increased litterfall compared with natural needle abscission in October.

Climatic data and model development. A climate data logger (HOBO Pro v2; Onset) was placed in the canopy of a nearby mature eastern white pine bordering the clear cut to log daily temperature $\left({ }^{\circ} \mathrm{C}\right)$ and percent relative humidity at 1-h intervals throughout the 2014 and 2015 growing seasons. A rain gauge placed in the center of the clear cut, alongside the center spore trap, recorded cumulative rainfall (in millimeters) and was collected at 4-day intervals; daily rainfall was not recorded.

To determine the effects of environmental parameters on spore loads, three climatic variables were considered for model parameterization: 4-day cumulative rainfall, temperature, and relative humidity (Boateng and Lewis 2015; Fitt et al.1989; Skilling and Nicholls 1974). Temperature and relative humidity variables were expanded for model parameterization to include average daily $(24 \mathrm{~h})$, daytime (6 A.M. to 8 P.M.), and overnight (8 P.M. to 6 A.M.) values as well as average minimum and maximum values for these three time intervals. To better understand how climate variables affected spore release and abundance, variables were modeled against spore data collected from June only, July only, and both June and July. A linear stepwise multiple regression analysis in JMP Pro 11.2.1 (SAS Institute Inc.) was used to select for variables that most accurately predicted spore abundance (Card et al. 1988; Liu et al. 2007). The Akaike Information Criterion with small sample correlation (Burnham and Anderson 2002; Hurvich and Tsai 1989), adjusted $R^{2}$, and variance inflation factor (VIF) of variables with a threshold of 4 (Montgomery and Peck 1992) were used to identify the best models. The VIF was used to test for multicollinearity between variables in the model. We reported both individual and multiple variable models that best fit and explained field observations. Additionally, 4-day cumulative rainfall and spore counts were modeled using a logistic regression analysis, with rainfall as a nominal factor categorized as 1 if rainfall occurred and 0 if rainfall was absent during the collection period.

Statistical analysis. All data collected from the three source trees during both sampling periods were used for statistical analysis performed using JMP Pro 11.2.1. Spore counts from the four slides on each support were averaged. Mean counts for each interval distance from the source tree $(0,3.05$, and $6.1 \mathrm{~m})$ were then averaged for the three source trees. In order to determine when peak spore release occurred, the mean number of spores observed every 4 days for each interval was subsequently added to the previous 4-day spore count to create a cumulative spore-trapped progress curve (Kranz 1974). A logistic 3P curve, which assumes that the data do not have a lower asymptote, was fit to the sigmoid nature of the data and used to graphically analyze the slope of the data to determine peak spore release. The $3 \mathrm{P}$ curve was used because the data did not contain a lower asymptote because initial spore release was zero prior to the first spore observation. To determine overall spore release, spore counts were averaged for all intervals and log transformed to fit the assumptions of analysis of variance (ANOVA) (Boateng and Lewis 2015). Spore counts were plotted separately by year for graphical analysis of the relative number of spores dispersed at 4-day intervals. ANOVA were used to determine differences in spore release by month, year, and distance. Additionally, a regression analysis with linear mixed effects was used to model the relationship between distance from inoculum source and spore counts. Distance was treated as a fixed effect and fit as a continuous variable, whereas year and tree were treated as random effects due to the year-toyear and tree-to-tree variation (Boateng and Lewis 2015).

\section{RESULTS}

Patterns of spore dispersal. Passive spore traps successfully trapped L. acicola spores released from eastern white pine source trees. During both sampling periods, only conidia were trapped on microscope slides; ascospores were not observed. Spores were observed on 4 of 51 collection dates on the central spore trap throughout both study periods, indicating that a dispersal distance of $60.6 \mathrm{~m}$ could be reached. Both study years showed similar trends in spore dispersal, with differences only in the onset of spore dispersal and abundance of spores released (Figs. 1, 2, and 3). In the 2014 sampling period, the first spores were observed on 13 May but not again until 29 May, despite the fact that rainfall occurred between these dates (Fig. 1A). The initial spore release in the 2015 sampling period was not observed until 21 May, after a couple weeks of $>70 \%$ relative humidity (Fig. 2C). Aside from the slight difference in the initial dispersal event, both years showed identical trends of increased spore release during the month of June, peaking approximately 14 to 18 June, and slowly decreasing throughout the remainder of the summer (Fig. 1, 2, and 3). The number of conidia 
observed in the month of June was significantly greater than in all other months, both overall and at each distance interval $(P<0.001)$. This was especially true in 2015 , when the greatest number of conidia in both years was observed from 14 to 22 June (Fig. 2), in the midst of an observed field defoliation event of eastern white pine needles (Fig. 4). Spore trap data from both years revealed that there was also a significant increase in the number of conidia observed in the 2015 study period compared with the 2014 study period $(P=0.0015)$, due to the greater relative humidity and presence of rainfall, during the field-observed defoliation event (14 to 26 June) in 2015 versus 2014 (Figs. 1A and C and 2A and C). Differences between years at each distance interval only showed significant increases in conidial abundance in 2015 at $0 \mathrm{~m}(P=0.03)$ and $3.05 \mathrm{~m}(P=0.04)$ from a source tree; both years showed similar spore counts at $6.1 \mathrm{~m}$ $(P=0.081)$. Although there was a greater number of spores observed at the $3.05-\mathrm{m}$ interval from 2014 to 2015 , both years exhibited the greatest abundance of conidia at $0 \mathrm{~m}(P<0.001)$ (Fig. 3).

It was not uncommon to observe conidia at the 3.05- and $6.1-\mathrm{m}$ intervals. However, the number of conidia trapped from each source tree throughout both sampling years significantly decreased with increasing distance from the source tree $(P<0.01)$. The regression equation $\log _{10} y=0.2435-0.008649 x$ provided the best fit for the relationship between distance and spore abundance, where $y$ is the average number of conidia collected from each distance during the sampling period for both years and $x$ is the distance from the source tree.

Litterfall. During the first year of the study, the amount of second- and third-year foliage cast in June significantly exceeded the amount of foliar biomass collected in May $(P<0.0001)$, July $(P=0.0006)$, August $(P<0.0001)$, and September $(P<0.0001)$
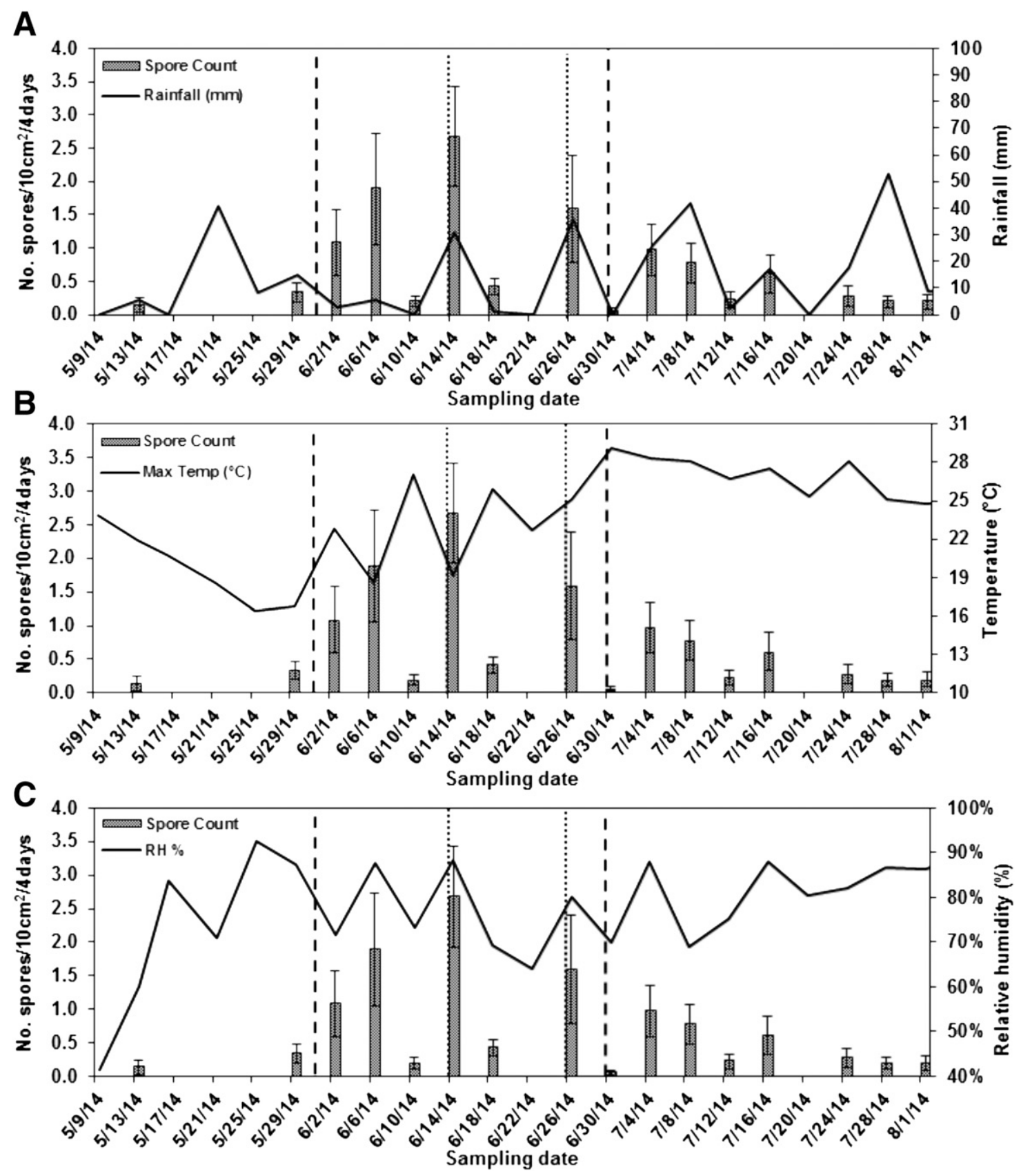

Fig. 1. Mean count of Lecanosticta acicola conidia per $10 \mathrm{~cm}^{2}$ collected from all intervals $(0,3.05$, and $6.1 \mathrm{~m})$ from source trees in 2014 with imposed climatic variables: A, 4-day cumulative rainfall; $\mathbf{B}$, mean 4-day maximum daily temperature; and $\mathbf{C}$, mean 4-day daily relative humidity. Error bars indicate standard error, region between long-dotted vertical lines indicates the month of June, and region between short-dotted vertical lines indicates field-observed defoliation event of Pinus strobus needles at the Massabesic Experimental Forest in Lyman, ME. 
2014. The normalized foliar biomass for June $\left(36.5 \mathrm{~g} \mathrm{~m}^{-2}\right)$ was not significantly different $(P=0.1209)$ from the natural needle abscission observed in October (44.5 $\mathrm{g} \mathrm{m}^{-2}$ ) (Fig. 4). Litterfall measurements in 2015 produced a similar trend, where the June defoliation event significantly exceeded observed litterfall in May $(P<0.0001)$, July $(P=0.0009)$, August $(P=0.0023)$, and September $(P=0.0005)$ (Fig. 4). In 2015, the natural needle abscission in October was significantly greater than the June defoliation event $(P<0.0001)$, with a mean foliar litter biomass accumulation of 67.4 and $28.3 \mathrm{~g} \mathrm{~m}^{-2}$, respectively. The defoliation event in 2016 was similar to 2014 because June litterfall $\left(38.16 \mathrm{~g} \mathrm{~m}^{-2}\right)$ was not significantly different $(P=0.7173)$ than the amount of natural needle abscission observed in October $\left(35.74 \mathrm{~g} \mathrm{~m}^{-2}\right)$. Furthermore, June litterfall significantly exceeded the amount of foliar biomass collected in
May $(P=0.0002)$, July $(P=0.017)$, August $(P=0.0009)$, and September $(P=0.0002) 2016$.

Compiling monthly litterfall resulting from WPND-induced defoliation (May, June, and July) equated to a loss of 49.7, 32.4, and $55.3 \%$ of the total growing season litterfall in 2014, 2015, and 2016, respectively, where the total growing season litterfall is the sum of all foliar biomass collected in May through October. These data indicate that white pine infected with $L$. acicola cast a significant amount of the total observed foliar biomass during the summer months, with only $37.4,51.1$, and $32.2 \%$ of the total seasonal litterfall occurring at natural abscission in October 2014, 2015, and 2016, respectively. June defoliation totals amounted to 30.6, 21.5 , and $34.4 \%$ of the growing season total in 2014, 2015, and 2016, respectively. These results show a dramatic shift in litterfall

A

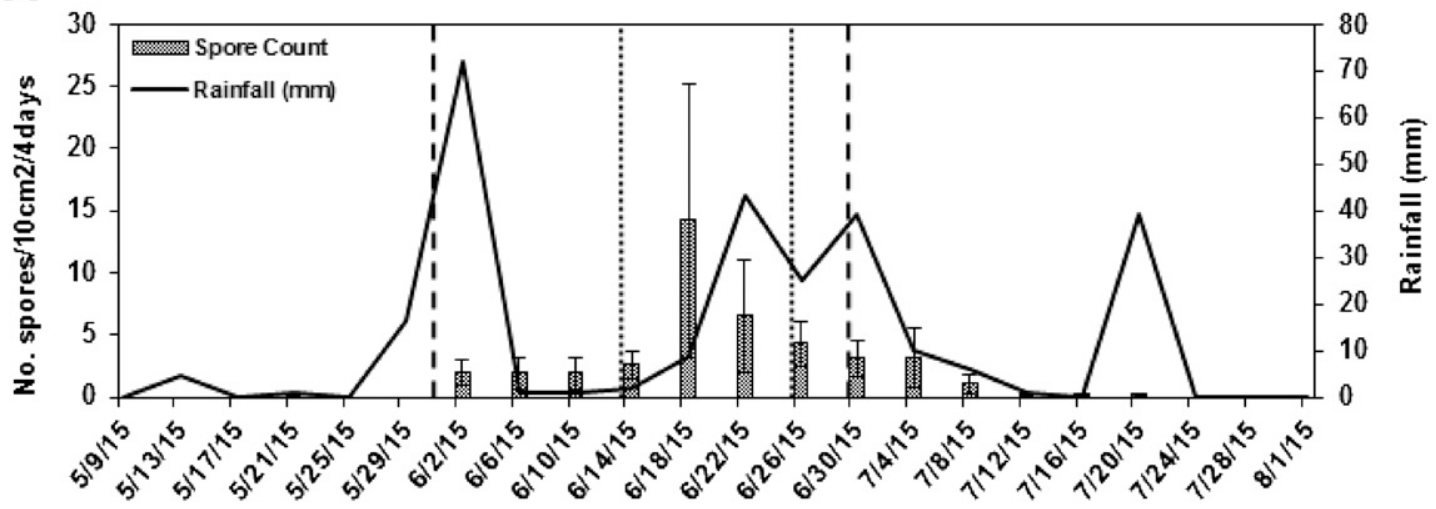

B

Sampling date
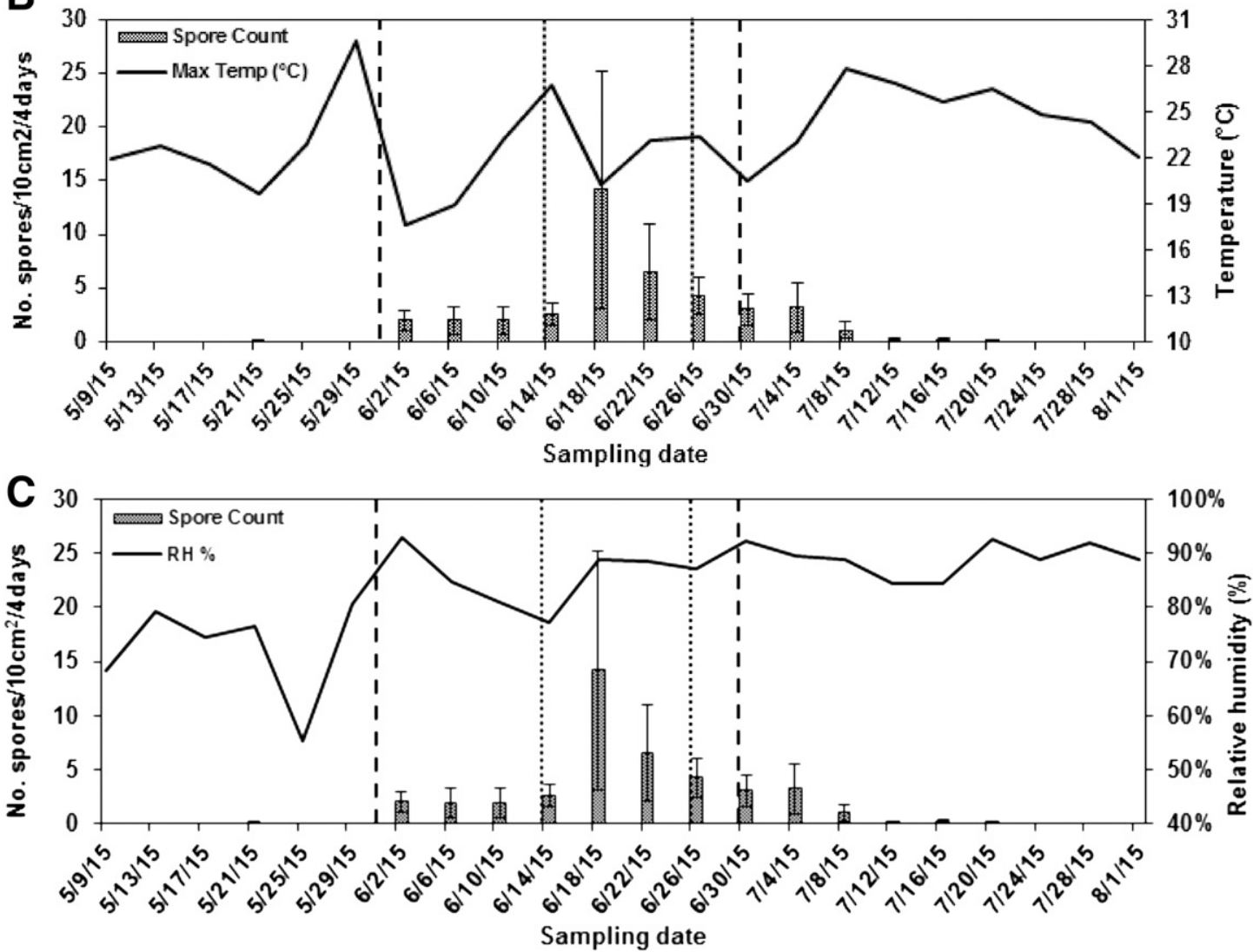

Fig. 2. Mean count of Lecanosticta acicola conidia per $10 \mathrm{~cm}^{2}$ collected from all intervals $(0,3.05$, and $6.1 \mathrm{~m})$ from source trees in 2015 with imposed climatic variables: A, 4-day cumulative rainfall; $\mathbf{B}$, mean 4-day maximum daily temperature; and $\mathbf{C}$, mean 4-day daily relative humidity. Error bars indicate standard error, region between long-dotted vertical lines indicates the month of June, and region between short-dotted vertical lines indicates field-observed defoliation event of Pinus strobus needles at the Massabesic Experimental Forest in Lyman, ME. 


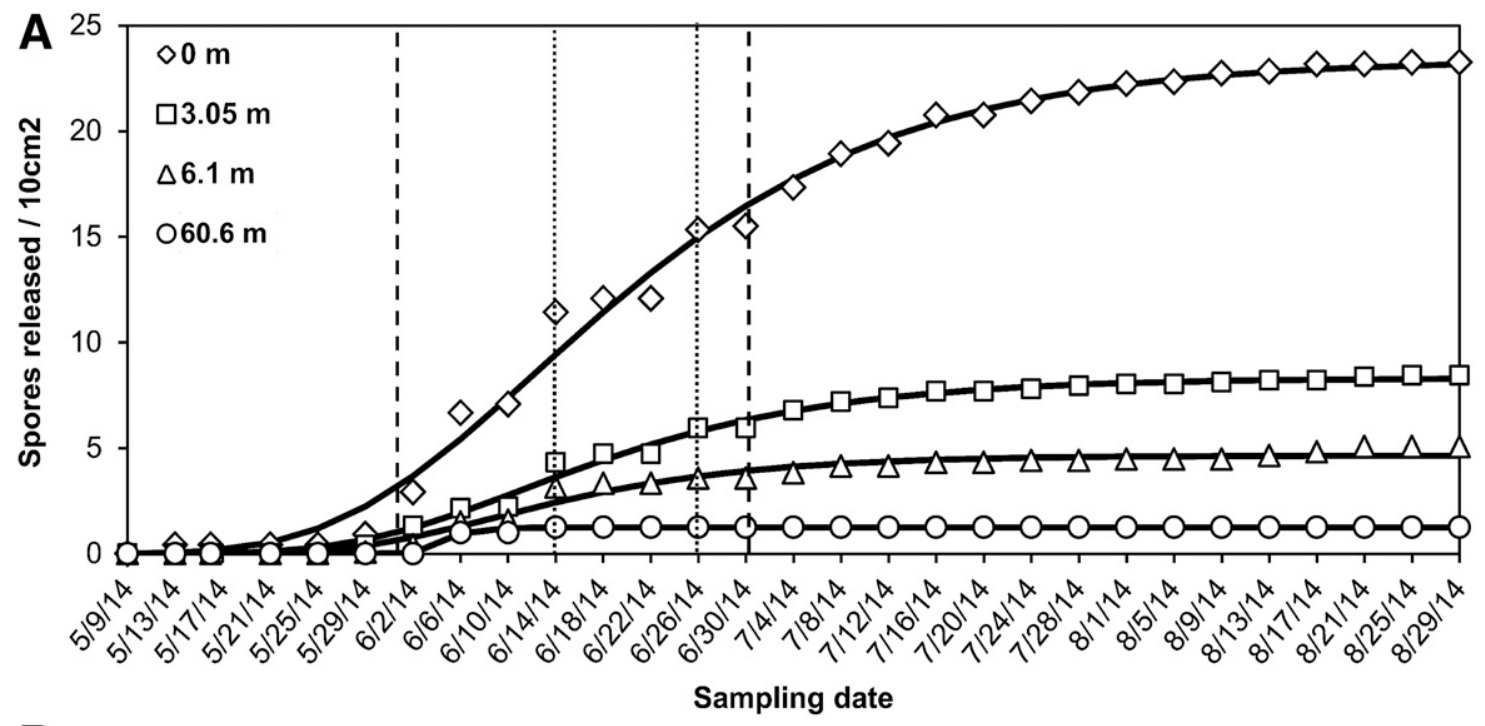

B

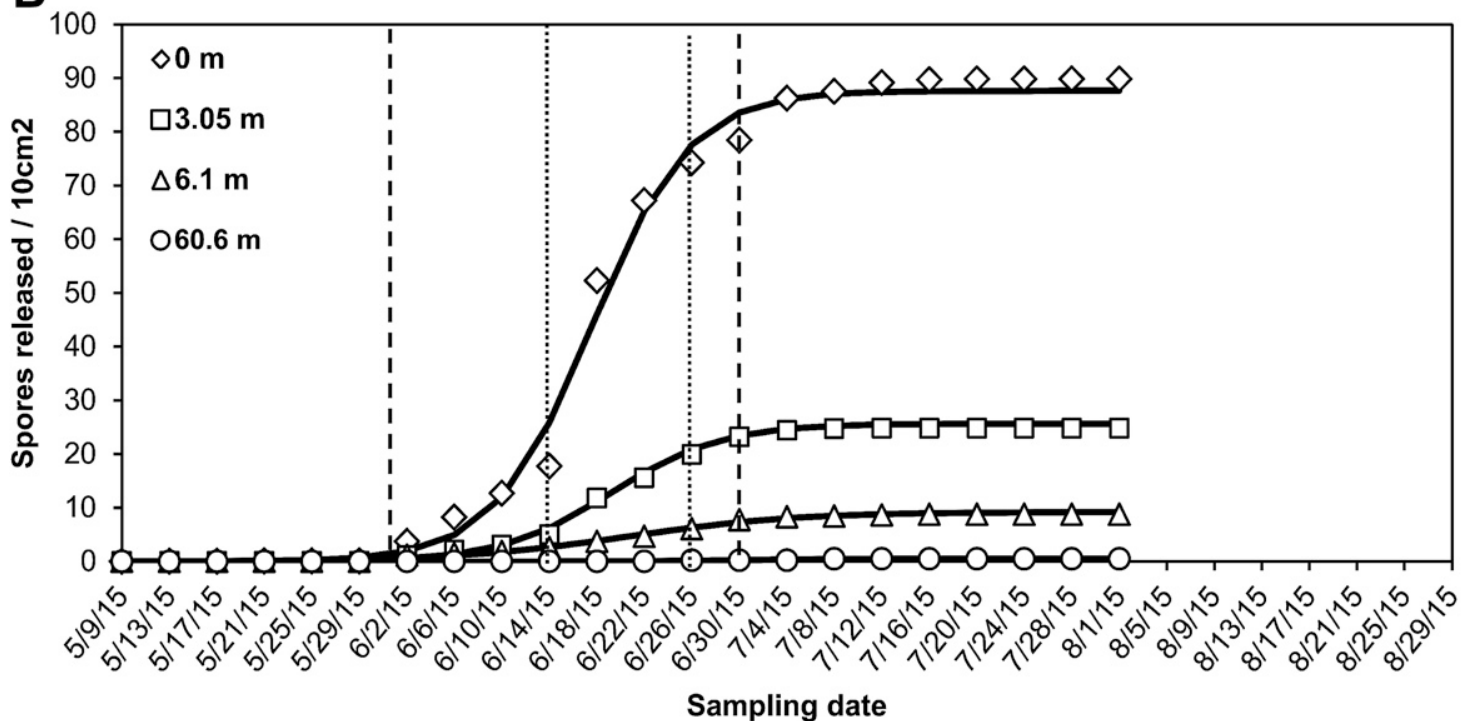

Fig. 3. Cumulative abundance of Lecanosticta acicola spores trapped at $0,3.05,6.1$, and $60.6 \mathrm{~m}$ from each of three infected Pinus strobus trees during May to August A, 2014 and B, 2015 at the Massabesic Experimental Forest in Lyman, ME. Points were fit with a 3P logistic curve (solid lines) to determine peak spore release. The region between long-dotted vertical lines indicates the month of June and the region between short-dotted vertical lines indicates observed defoliation event of $P$. strobus needles.

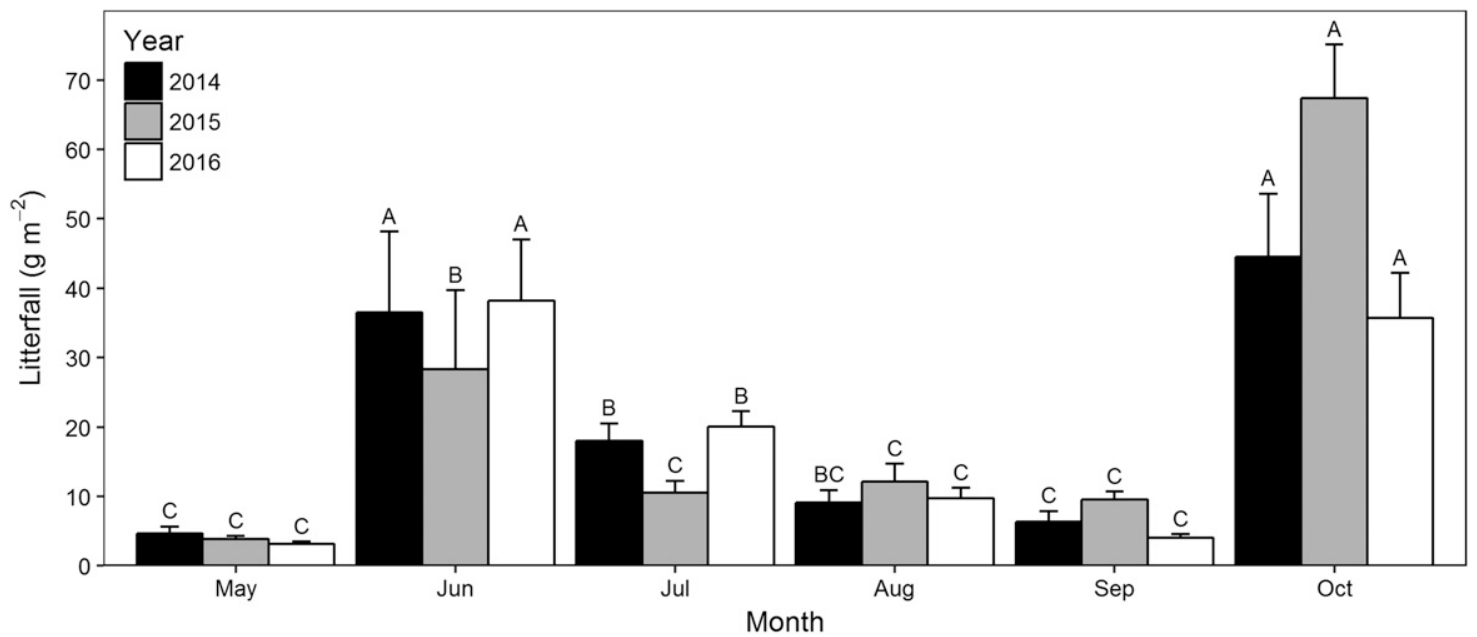

Fig. 4. Monthly litterfall totals normalized by Pinus strobus basal area (square meters) within plots measured at the Massabesic Experimental Forest, Lyman, ME for 2014 (black), 2015 (gray), and 2016 (white). Error bars represent one standard error. Months containing the same letters are not significantly different within the sampled year $(P>0.05)$. 
distribution from natural needle abscission in October to large defoliation events occurring during May to July due to WPND.

Effects of climate on dispersal. Weather data during June and July was used to determine the effects of climate on spore abundance and dispersal. Although the peak spore release was observed during the month of June, spores were also present through mid-July and, therefore, were included in model analysis. Although more spores were observed in association with rain events, spores were occasionally seen after periods of no rain, although in much lower abundance (Figs. 1A and 2A). Consequently, no relationship was found between cumulative 4-day rainfall and the abundance of spores dispersed during the months of June $\left(R^{2}=0.14, P=0.15\right)$, July $\left(R^{2}=0.01, P=0.72\right)$, and both June and July $\left(R^{2}=0.07, P=0.14\right)$. However, a logistic regression analysis indicated that the occurrence of rainfall significantly influenced spore abundance $(P<0.001)$, indicating that rainfall frequency was more important for $L$. acicola dispersal and abundance than the cumulative 4-day rainfall.

Results showed a general negative relationship between temperature and spore abundance, particularly average maximum daily temperature. This trend was evident during the month of June $\left(R^{2}=\right.$ $0.16, P=0.07$ ) but was only significant during the combined months of June and July $\left(R^{2}=0.32, P=0.001\right)$ (Table 1$)$. Fewer conidia were trapped as average maximum temperatures began to increase above $25^{\circ} \mathrm{C}$, coinciding with the start of July (Figs. 1B and 2B). A positive relationship was found between relative humidity and the number of spores trapped, with relative humidity being the climatic variable which had the most significant effect on spore abundance. During the month of June, all relative humidity parameters significantly influenced spore abundance, with average minimum overnight relative humidity being the best predictor $\left(R^{2}=0.66, P<0.0001\right)$ (Table 1 ). In the combined analysis of June and July, only average daytime relative humidity was found to be significant $\left(R^{2}=0.13\right.$, $P=0.05$ ) (Table 1). Spores were rarely found during periods when relative humidity was $<70 \%$ and when rainfall was infrequent. These results are most evident during the period of field-observed defoliation (14 to 26 June).

In 2014, this period exhibited the lowest relative humidity of the entire sampling period, a low occurrence of rainfall, and average maximum daily temperatures were $>25^{\circ} \mathrm{C}$, resulting in very little spore release (Fig. 1B and C). In contrast, during 2015, this period showed relative humidity values $>80 \%$, a high occurrence of rainfall, and average maximum daily temperatures $<25^{\circ} \mathrm{C}$, resulting in spore abundances of up to six times greater than in 2014 (Fig. 2B and C). Although June weather appeared to be the best predictor of spore abundance, the addition of July weather data combined with data from June showed significant relationships, with some individual climatic variables and two-factor models containing both temperature and relative humidity (Table 1), providing a better understanding of the nature of L. acicola spore dispersal from mature eastern white pine trees in a natural forest setting.

\section{DISCUSSION}

The objective of this study was to understand the effect of relative humidity, rainfall, and temperatures on the dispersal of L. acicola, the primary foliar pathogen associated with the defoliation of eastern white pine. In addition, our secondary objective was to determine whether defoliation caused by L. acicola has caused a shift in the litterfall distribution from natural needle abscission in October to large defoliation events during the summer months. This result provides evidence for the potential of WPND-induced defoliation of the second- and third-year needles to cause harmful growth effects

TABLE 1. Regression and model statistics for effects of climatic variables on the average abundance of Lecanosticta acicola conidia found on spore traps placed at different distance intervals (0 to $6.1 \mathrm{~m}$ ) from three mature eastern white pine trees (Pinus strobus) at the Massabesic Experimental Forest in Lyman, ME

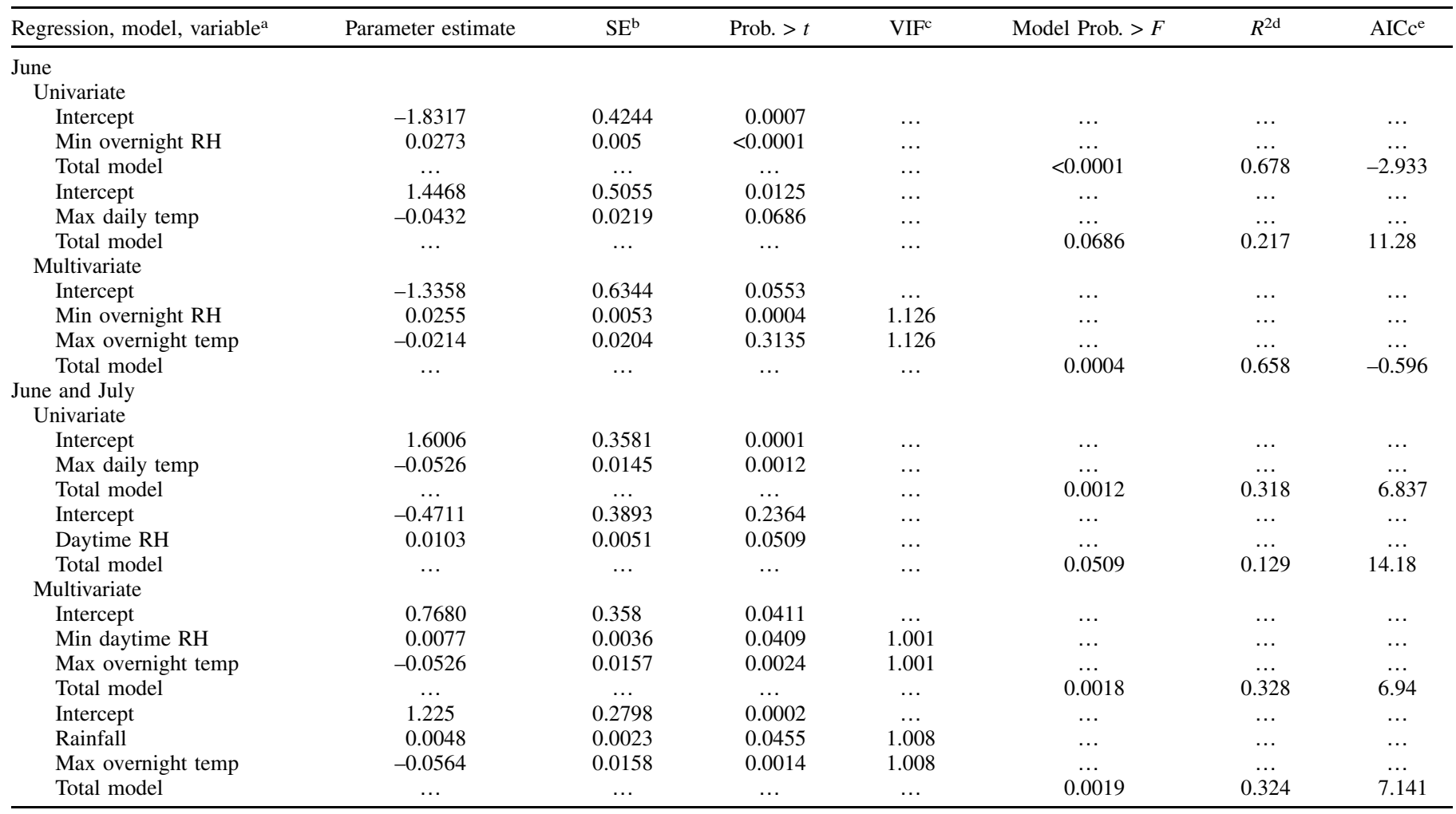

${ }^{a}$ Climatic measurements were averaged together over a 4-day interval: daily ( 24 h), daytime (6 a.m. to 8 p.m.), and overnight $(8$ p.m. to 6 a.m.). Min = minimum,

$\mathrm{RH}=$ relative humidity, Max $=$ maximum, and temp = temperature.

b Standard error.

c VIF = variance inflation factor; variables with values $<4$ were considered not to be collinear.

d Adjusted $R^{2}$ values are shown for multivariate models.

e $\mathrm{AICc}=$ Akaike Information Criterion with small sample correlation. 
through the loss of 32.4 to $55.3 \%$ of a mature tree's total observed foliar litterfall in May, June, and July. Similarly, Linzon (1958) studied the effects of artificial defoliation on the growth response of 20-year-old eastern white pine. Their results indicate that the removal of any year's foliage had an effect on vertical growth, while removal of the second-year needles in combination with another year's foliage severely reduced diameter growth (Linzon 1958). Because $L$. acicola is only observed on second- and third-year needles of eastern white pine, our litterfall results along with Linzon's results can help foresters understand the potential harmful effects of repeated defoliations.

L. acicola was found occurring on mature and regenerating eastern white pine trees since the 1950s in the southeastern United States (Boyce 1959), since 1991 in the Mid-Atlantic and Midwest states (Stanosz et al. 1991), and since 2006 in the northeastern United States (Broders et al. 2015; Munck et al. 2011, 2012). Based upon its ubiquitous presence throughout the region (Wyka et al. 2017) and evidence of variability in virulence among strains (Kais 1971), we hypothesize that the current outbreak of L. acicola was caused by a change in the regional climate that has allowed an endemic strain to increase in abundance to epidemic proportions (Wyka et al. 2017). This is supported by the Janoušek et al. (2016) study that recently concluded, through molecular characterization, that there is no evidence that a southern strain has spread north.

Our results generally agree with the findings of a 2-year spore dispersal study conducted on Scots pine plantations in Wisconsin and Minnesota of L. acicola ascospores, in which no L. acicola ascospores were observed on any of the 1,300 microscope slides used as passive spore traps (Skilling and Nicholls 1974). This study further confirmed the absence of the sexual stage by examining numerous infected Scots pine needles and finding no sexual fruiting bodies (pseudothecium). Other studies of L. acicola have primarily found the sexual stage present in the southern United States (Kais 1971; Phelps et al. 1978), with the most northern record of the sexual stage occurring near Ashland, MO on ponderosa pine (P. ponderosa) (Luttrell 1949). Our results are consistent with those found by Skilling and Nicholls (1974), although our sampling strategy may not have effectively captured wind-dispersed ascospores because spore traps were placed at short distances from source trees and did not contain any suction. Notwithstanding, our sampling surveys, along with others, of diseased eastern white pine needles throughout the northeastern United States have not revealed any sightings of sexual fruiting structures (Broders et al. 2015; Munck et al. 2011, 2012; Wyka et al. 2017). Furthermore, Janoušek et al. (2016) recently determined that the northern Midwest and northeastern United States L. acicola isolates are biased by a population of a single haplotype (MAT1). This indicates that sexual recombination with the MAT2 mating type is very infrequent, which could explain the lack of ascospores found during our dispersal experiment and sampling efforts (Broders et al. 2015; Munck et al. 2011, 2012; Wyka et al. 2017). This bias toward asexual reproduction suggests that the primary means of dispersal of L. acicola throughout the northeastern United States is through rain-splash-dispersed conidia.

Conidia of L. acicola were first observed in the beginning of May 2014 but consistent dispersal did not occur until early June. Conidial dispersal peaked in mid-June (14 to 26 June), after which the number of trapped conidia began to decrease steadily throughout July and August. This peak corresponded to a significant eastern white pine defoliation event at the MEF (Fig. 4) and previous events throughout the northeastern United States (Munck et al. 2011, 2012). In general, the results of Skilling and Nicholls (1974) showed similar trends but occurred on an earlier time scale, with a consistent onset time of conidia release occurring in early May and a dispersal peak from 5 to 19 June. Similarly, after the peak, conidial abundance drastically declined throughout the rest of the summer (Skilling and Nicholls 1974). This inconsistency in onset time may be caused by drier conditions in Maine during the month of May, which may have slowed the development of conidia because high humidity is necessary for the development of conidia in infected needles (Kais 1975). However, it is not possible to determine the cause behind this inconsistency because Skilling and Nicholls (1974) did not report average relative humidity along with their observed conidia counts.

Along with slight differences in the timing of spore dispersal, our study also showed greater dispersal distances compared with the results of Skilling and Nicholls (1974). From sapling Scots pine trees $<3.05 \mathrm{~m}$ tall, conidia were rarely observed further than $1.5 \mathrm{~m}$ from a source tree, with significant reduction in spore abundance occurring at $0.3 \mathrm{~m}$ from the tree (Skilling and Nicholls 1974). In our study, conidia were found in greater abundances at $0 \mathrm{~m}$ from the furthest reach of the branches (approximately $3.65 \mathrm{~m}$ from the trunk); however, it was not uncommon to find conidia 3.05 and $6.1 \mathrm{~m}$ away (Fig. 3). This difference in dispersal distance is most likely due to the difference in height between the two trees species rather than a variation in isolates or climates. Because L. acicola produces mucilage conidial masses on both Scots pine and eastern white pine, rain splash is the primary method of dispersal, because the mucilage prevents dispersal by wind (Fitt et al. 1989). During our study, spore trapping supports were placed well below the canopy, because it would have required a support of approximately $12 \mathrm{~m}$ to reach the bottom portion of the canopy. This could explain the observations of conidia $6.1 \mathrm{~m}$ away from an inoculum source because the large distance between spore trap and crown would allow a rain-splashed spore to have a larger trajectory, especially if strong winds were present (Aylor 1990). We attempted to account for this factor by placing supports in three cardinal directions; however, conidia were still observed at $6.1 \mathrm{~m}$ for all three source trees, suggesting that strong wind could play a role in the dispersal of rain-splashed spores. Spores could have reached the central trap by strong wind because a recent study has shown that Dothistroma septosporum (Dorogin) M. Morelet 1968, which has a dispersal mechanism similar to that of L. acicola, was recorded in excess of $1,400 \mathrm{~m}$ from an infection source (Mullett et al. 2016). In addition, spores on the central trap could have also been dispersed by insects because Skilling and Nicholls (1974) found evidence of this in their experiment.

Our results demonstrate the importance of climatic variables such as rainfall, temperature, and relative humidity on the abundance and dispersal of L. acicola conidia. Although amount of rainfall is one of the primary climatic factors affecting spore abundance of similar foliar pathogens (Boateng and Lewis 2015; Fitt et al. 1989), our logistic regression showed that the occurrence of rainfall was more important for L. acicola dispersal and abundance than the amount of rainfall. This is supported by the report by Skilling and Nicholls (1974), which indicated that L. acicola spore release was dependent on the occurrence of rainfall. Our data also indicate that relative humidity and temperature were the primary climatic factors affecting spore abundance. These results agree with previous research of $L$. acicola showing that needles containing mature acervuli can readily sporulate after 1 day in a moist chamber (OEPP/ EPPO 2005), and that high summer temperatures $\left(\geq 30^{\circ} \mathrm{C}\right)$ are detrimental to germination, growth, and sporulation (Kais 1975; Skilling and Nicholls 1974). Kais (1975) determined that at least three consecutive days of high humidity were essential for the development of infection, coinciding with development of mature acervuli. Similarly, during our study, spore abundance decreased when relative humidity dropped below $80 \%$ and spores were rarely observed when humidity was $<70 \%$. Regression analysis specifically determined that relative humidity was the most important factor during peak dispersal; however, as relative humidity continued to increase throughout the summer, spore abundance decreased. This decrease in spore abundance could have been caused by the concurrent increase in temperature which was found to negatively affect spore abundance. Another possible explanation for the decrease in spore abundance throughout the summer is a depletion of spore loads. Results from our spore trapping and 
litterfall collection show a decrease in spore abundance in July and August, most likely due to the lack of infected needles containing mature acervuli (second- and third-year needles), because these needles were cast in June (Fig. 4). Furthermore, because L. acicola takes a full year to incubate in newly infected eastern white pine needles (Boyce 1959; Munck et al. 2012; Stanosz et al. 1991), the current-year needles left on the tree after the June defoliation will not contribute to spore release that same year.

Lack of a significant relationship between the amount of rainfall and spore abundance differed from previous studies of WPND, in which Wyka et al. (2017) found cumulative spring precipitation to be the primary factor in predicting defoliation severity in the following year. However, this new finding does not dispute our previous finding. Although the amount of rainfall did not directly affect the number of spores trapped, our analysis shows that more spores are released after rain events. This indicates that rainfall does not affect the abundance of spores produced from an infected needle but is responsible for the dispersal of spores from infected needles. This dispersal allows for the spread and subsequent infection of new needles, which then have the potential to increase the observed defoliation of a tree (i.e., defoliation severity). Thus, without rainfall and periods of high relative humidity, few to no spores will disperse from infected needles, in turn decreasing the potential of new infections of needles within dispersal range.

This potential for decreases in new infections due to periods of low relative humidity and limited rainfall can be observed from spore and litterfall collection in this study. In June 2014, litterfall was not significantly different than natural needle abscission in October (Fig. 4), indicating a substantial premature defoliation event of $30.6 \%$ of the total growing season's litterfall. This large number of inoculum sources (infected second- and third-year needles) would suggest an equally large abundance of spores. However, prior to their abscission in June (14 to 26 June), the MEF received very little to no rain, particularly from 14 to 22 June, and had consistently low relative humidity $(<70 \%)$, resulting in very little spore abundance. Therefore, this low spore abundance resulted in low infection potential that was reflected in the June 2015 litterfall collection, which was $21.5 \%$ of the total growing season's litterfall and significantly lower than normal needle abscission in October (Fig. 4). However, prior to the 2015 defoliation event, the MEF received frequent rainfall from 14 to 22 June and had consistently high relative humidity $(>80 \%)$, resulting in significant increases in spore abundance (Fig. 2). Consequently, this high spore abundance suggests a higher infection potential that was reflected in increased disease severity and litterfall in 2016 (Fig. 4).

In conclusion, our results demonstrate that dispersal patterns of L. acicola are strongly influenced by climatic data. L. acicola within the northeastern United States starts to mature on infected needles during May, with spore production beginning at the end of May. Peak spore production occurs in June and is primarily influenced by minimum overnight relative humidity. The most notable spore abundance occurs during defoliation events from 14 to 26 June; if low relative humidity $(<70 \%)$ and infrequent rainfall is observed during this period, spore abundance will be significantly decreased. After the month of June, spore loads begin to decrease, most likely due to abscission of the infected second- and third-year needles during the premature defoliation events. In addition, this study shows that WPND-induced defoliation (May to July) of the secondand third-year needles can account for 32.4 to $55.3 \%$ of the total growing season litterfall, which is larger than the natural 10 to $15 \%$ abscission observed by Wang and Chen (2012) in eastern white pine stands in Ontario, Canada during the same months. Visible symptoms of L. acicola and other WPND-associated pathogens do not persist into the late summer and October; therefore, it is unlikely that a significant proportion of the measured October litterfall is resulting from needle infection. This defoliation may negatively affect tree health and growth, as documented by similar fungal defoliators of conifer species such as in Douglas-fir affected by
Swiss needle-cast (Kimberley et al. 2011). C. D. McIntire (unpublished) shows evidence of diameter growth reduction of mature P. strobus affected by L. acicola in natural stands that begin in 2009, coinciding with the start of the WPND outbreak in the northeastern United States. Together, the current and C. D. McIntire (unpublished) studies will provide valuable insight into the epidemiology of a native forest pathogen, L. acicola, in naturally established $P$. strobus forests. As observed trends of increasing spring temperature and precipitation in the northeastern United States continue to occur, it is likely that defoliation of eastern white pine by L. acicola will continue to be a regional issue for white-pine-dominated forests (Wyka et al. 2017). The results of the current study will help managers determine how far from symptomatic trees they might expect natural regeneration to be affected and make inferences about the expected disease severity the following year based on current-year climatic conditions. Finally, our study showed that spore traps were an effective and relatively inexpensive way to quantify spore dispersal that could be used by managers in other systems to determine critical distance at which seedlings could be planted from infected mature trees to avoid disease.

\section{ACKNOWLEDGMENTS}

We thank the United States Forest Service Northern Research Station for their assistance in allowing us to set up our spore trapping experiment at the Massabesic Experimental Forest, Lyman ME; and Forest Health State Cooperators from Maine, New Hampshire, and Vermont, along with all Forest Watch schools (Sant Bani School, Sanbornton, NH; Gilmanton Elementary School, Gilmanton, NH; Prospect Mountain High School, Alton, $\mathrm{NH}$; Keene High School, Keene, NH; The Dublin School, Dublin, NH; French Pond School, Woodsville, NH; Salem High School, Salem, NH; and Bath High School, Bath, ME) for collecting and sending in infected pine needles.

\section{LITERATURE CITED}

Aussenac, G. 2000. Interactions between forest stands and microclimate: Ecophysiological aspects and consequences for silviculture. Ann. For. Sci. 57:287-301.

Aylor, D. E. 1990. The role of intermittent wind in the dispersal of fungal pathogens. Annu. Rev. Phytopathol. 28:73-92.

Bingzhang, H., Xinglin, D., Chengyu, L., Guigin, L., and Yuping, Y. 1992. The development pattern of Dothistroma needle blight and its control. J. Northeast For. Univ. 3:43-53.

Boateng, K., and Lewis, K. J. 2015. Spore dispersal by Dothistroma septosporum in northwest British Columbia. Phytopathology 105:69-79.

Boyce, J. S., Jr. 1959. Brown spot needle blight on eastern white pine. Plant Dis. Rep. 43:420.

Broders, K. D., Munck, I., Wyka, S., Iriarte, G., and Beaudoin, E. 2015. Characterization of fungal pathogens associated with white pine needle damage (WPND) in northeastern North America. Forests 6:4088-4104.

Burnham, K. P., and Anderson, D. R. 2002. Model Selection and Multimodel Inference: A Practical Information-Theoretic Approach, 2nd ed. SpringerVerlag, New York.

Card, D. H., Peterson, D. L., and Matson, P. A. 1988. Prediction of leaf chemistry by the use of visible and near infrared reflectance spectroscopy. Remote Sens. Environ. 26:123-147.

EPPO/CABI. 2013. Mycosphaerella dearnessii and Mycosphaerella pini. Data Sheets on Quarantine Pests. Online publication. Prepared by CABI and EPPO for the EU under contract 90/399003. https://www.eppo.int/QUARANTINE/ data_sheets/fungi/SCIRSP_ds.pdf

Fitt, B. D. L., McCartney, H. A., and Walklate, P. J. 1989. The role of rain in dispersal of pathogen inoculum. Annu. Rev. Phytopathol. 27:241-270.

Gibson, I. A. S. 1980. Two pine needle fungi new to Colombia. Trop. Pest Manage. 26:38-40.

Hansen, E. M., and Goheen, E. M. 2000. Phellinus weirii and other native root pathogens as determinants of forest structure and process in western North America. Annu. Rev. Phytopathol. 38:515-539.

Heimann, M. F., Stanosz, G. R., and Worf, G. L. 1997. Pine needle diseases: Brown spot and Lophodermium needlecast. Online publication. University of Wisconsin Extension. http://learningstore.uwex.edu/assets/pdfs/A2608.pdf

Hinckley, T. M., Keyes, M. R., Martin, T. A., and Sprugel, D. G. 1999. Lessons from montane forests of the Pacific Northwest. Phyton (Buenos Aires, Argent.) 39:73-84.

Hintsteiner, M., Cech, T. L., Halmschlager, E., Stauffer, C., and Kirisits, T. 2012. First report of Mycosphaerella dearnessii on Pinus nigra var. nigra in Austria. For. Pathol. 42:437-440. 
Holdenrieder, O., and Sieber, T. N. 1995. First report of Mycosphaerella dearnessii in Switzerland. Eur. J. For. Pathol. 25:293-295.

Huang, Z. Y., Smalley, E. B., and Guries, R. P. 1995. Differentiation of Mycosphaerella dearnessii by cultural characters and RAPD analysis. Phytopathology 85:522-527.

Hurvich, C. M., and Tsai, C.-L. 1989. Regression and time series model selection in small samples. Biometrika 76:297-307.

Jankovský, L., Palovčíková, D., and Tomšovský, M. 2009. Brown spot needle blight associated with Mycosphaerella dearnessii occurs on Pinus rotundata in the Czech Republic. Plant Pathol. 58:398.

Janoušek, J., Wingfield, M. J., Marmolejo Monsivais, J. G., Jankovský, L., Stauffer, C., Konečný, A., and Barnes, I. 2016. Genetic analyses suggest separate introductions of the pine pathogen Lecanosticta acicola into Europe. Phytopathology 106:1413-1425.

Jurc, D., and Jurc, M. 2010. Mycosphaerella dearnessii occurs in Slovenia. Plant Pathol. 59:808.

Kais, A. G. 1971. Dispersal of Scirrhia acicola spores in southern Mississippi. Plant Dis. Rep. 55:309-311.

Kais, A. G. 1975. Environmental factors affecting brown spot infection on longleaf pine. Phytopathology 65:1389-1392.

Kimberley, M. O., Hood, I. A., and Knowles, R. L. 2011. Impact of Swiss needle-cast on growth of Douglas-fir. Phytopathology 101:583-593.

Kranz, J. 1974. The role and scope of mathematical analysis and modeling in epidemiology. Pages 7-54 in: Epidemics of Plant Diseases: Mathematical Analysis and Modeling. J. Kranz, ed. Springer, Berlin, Heidelberg, New York.

La Porta, N., and Capretti, P. 2000. Mycosphaerella dearnessii, a needle-cast pathogen on mountain pine (Pius mugo) in Italy. Plant Dis. 84:922.

Linzon, S. N. 1958. The effect of artificial defoliation of various ages of leaves upon white pine growth. For. Chron. 34:51-56.

Liu, Z. Y., Huang, J. F., Shi, J. J., Tao, R. X., Zhou, W., and Zhang, L. L. 2007. Characterizing and estimating rice brown spot disease severity using stepwise regression, principle component regression and partial least-square regression. J. Zhejiang Univ. Sci. B 8:738-744.

Luttrell, E. S. 1949. Scirrhia acicola, Phaeocryptopus pinastri, and Lophodermium pinastri associated with the decline of ponderosa pine in Missouri. Plant Dis. Rep. 33:397-401.

Montgomery, D. C., and Peck, E. A. 1992. Page 527 in: Introduction to Linear Regression Analysis, 2nd ed. John Wiley and Sons, New York.

Mullett, M. A., Tubby, K. V., Webber, J. F., and Brown, A. V. 2016. A reconsideration of natural dispersal distances of the pine pathogen Dothistroma septosporum. Plant Pathol. 65:1462-1472.

Munck, I., Burns, B., Ostrofsky, W., Lombard, K., and Weimer, J. 2012. Eastern white pine needle damage survey, 2011 in Maine, New Hampshire, and Vermont. Online publication. U.S. Dep. Agric. For. Serv. https:// extension.unh.edu/resources/files/Resource003566_Rep5105.pdf
Munck, I. A., Ostrofsky, W. D., and Burns, B. 2011. Pest Alert: Eastern white pine needle damage. U.S. Dep. Agric. For. Serv. Northeastern Area State and Private Forestry, NA-PR-01-11.

OEPP/EPPO. 2005. Mycosphaerella dearnessii. Bull. OEPP/EPPO Bull. 35: 299-302.

Phelps, W. R., Kais, A. G., and Nicholls, T. H. 1978. Brown-spot needle blight of pines. U.S. Dep. Agric. Forest Insect and Disease Leaflet 44.

Pietravalle, S., van den Bosch, F., Welham, S. J., Parker, S. R., and Lovell, D. J. 2001. Modelling of rain splash trajectories and prediction of rain splash height. Agric. For. Meteorol. 109:171-185.

Podger, F. D. 1978. Studies on the effect of some climatic factors and spore dispersal on infection of two species of Pinus by Dothistroma pini. Ph.D. thesis, University of Auckland, New Zealand.

Quaedvlieg, W., Groenewald, J. Z., de Jesús Yáñez-Morales, M., and Crous, P. W. 2012. DNA barcoding of Mycosphaerella species of quarantine importance to Europe. Persoonia 29:101-115.

Reich, P. B. 1998. Variation among plant species in leaf turnover rates and associated traits: Implications for growth at all life stages. Pages 467-487 in: Inherent Variation in Plant Growth: Physiological Mechanisms and Ecological Consequences. H. Lambers, H. Poorter, and M. M. I. van Vuuren, eds. Backhuys, Leiden, The Netherlands.

Siggers, P. V. 1944. The brown spot needle blight of pine seedlings. U.S. Dep. Agric. Tech. Bull. 870 .

Skilling, D. D., and Nicholls, T. H. 1974. Brown spot needle disease-Biology and control in Scots pine plantations. U.S. Dep. Agric. For. Serv. Research Paper NC-109.

Stanosz, G., Cummings, J., and Jackson, W. 1991. Pest Alert: Brown spot needle blight of eastern white pine. U.S. Dep. Agric. For. Serv. Northeastern Area, NA-PR-03-91.

Stone, T. 2006. Massabesic Experimental Forest, Alfred and Lyman, Maine. Online publication. U.S. Dep. Agric. For. Serv. Northern Research Station. https://www.fs.fed.us/ne/durham/4155/massabes.htm

Vose, J. M., and Allen, H. L. 1988. Leaf area, stemwood growth, and nutrition relationships in loblolly pine. For. Sci. 34:547-563.

Wang, R., and Chen, J. M. 2012. Seasonal life area index variations derived from needle growth and fall measurements in two eastern white pine (Pinus strobus L.) stands. Pages 413-417 in: Proc. 2012 IEEE 4th Int. Symp. Plant Growth Modeling, Simulation, Visualization and Application, PMA 2012.

Wyka, S. A., and Broders, K. D. 2016. The new family Septorioideaceae, within the Botryosphaeriales and Septorioides strobi as a new species associated with needle defoliation of Pinus strobus in the United States. Fungal Biol. 120:1030-1040.

Wyka, S. A., Smith, C., Munck, I. A., Rock, B. N., Ziniti, B. L., and Broders, K. 2017. Emergence of white pine needle damage in the northeastern United States is associated with changes in pathogen pressure in response to climate change. Glob. Change Biol. 23:394-405. 